\title{
Islam in Madurese's Cosmological Interpretation: Structural Analysis of Tanean Lanjeng in Madura
}

\author{
Zuhri Humaidi \\ Institut Agama Islam Negeri Kediri, Indonesia \\ email: kenhumaidi@gmail.com
}

\begin{abstract}
Madurese are known as devout Muslims. Islam and Madurese culture are two integrated identities like two sides of a coin. Islam and Madurese culture shape the value, word view and culture of Madurese people. Then, how significance are these two aspects in its cosmological order? What is Madurese's cognitive structure in interpreting their world and forming a material culture? These questions are problems that will be revealed in this paper through research on Tanean Lanjeng, which is a typical settlement pattern in Madura. With Levi Strauss's structuralism approach, Tanean Lanjeng is seen as a code of conduct from the cognitive structure of the Madura people who formulate their ideas and actions. Tanean Lanjeng is a surface structure of a culture while the cognitive aspect is a deep structure. This paper further elaborates that the tanean lanjeng settlements in Madura not only have practical and social functions but show certain meanings that reflects the thinking and worldview of the Madurese. Values such as the equality of male and female relations, strong kinship ties, respect for certain figures, and Islam that are so deeply rooted in a structure that determines how Madurese behave, shape culture and interpret the world around them.

[Orang Madura dikenal sebagai pemeluk Islam yang taat. Keislaman dan kemaduraan merupakan identitas yang integral ibarat dua sisi dari mata uang yang sama. Keislaman dan kemaduraan membentuk nilai, word view dan budaya orang Madura. Namun bagaimana bobot dan
\end{abstract}

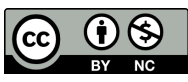

DOI: $10.19105 /$ karsa.v28i2.3057 
signifikansi dua aspek tersebut dalam tatanan kosmologinya? Bagaimanakah struktur kognitif Orang Madura di dalam menafsirkan dunianya dan membentuk kebudayaan yang sifatnya material? Pertanyaan tersebut merupakan problematik yang akan diungkapkan dalam tulisan ini melalui penelitian terhadap tanean lanjeng sebagai pola pemukiman yang khas madura. Dengan pendekatan strukturalisme Levi Strauss, tanean lanjeng dilihat sebagai code of conduct dari struktur kognitif orang madura yang membetuk gagasan dan tindakannya. Tanean lanjeng merupakan struktur luar kebudayaan (surface structure) sedangkan segi kognitif merupakan struktur dalamnya (deep structure). Tulisan ini selanjutnya menguraikan bahwa permukiman tanean lanjeng di Madura tidak hanya memiliki fungsi praktis dan sosial tetapi menunjukkan makna-makna tertentu yang mencerminkan struktur berfikir dan pandangan dunia orang Madura. Nilai-nilai seperti kesetaraan relasi laki-laki dan perempuan, kuatnya ikatan kekerabatan, penghormatan terhadap tokoh-tokoh tertentu serta keislaman yang begitu mengakar tertata dalam sebuah struktur yang menentukan bagaimana orang Madura bersikap, membentuk kebudayaan dan menafsirkan dunia di sekelilingnya.]

Keywords: tanean lanjeng; structuralism; cognitive structure; code of conduct.

\section{Introduction}

In the life of community, especially those who are not involved in studies on Madura, Madurese society is only known through a number of stereotypes, some of which are based on little information about this community. Madurese are portrayed as brave, hard, rude, murderous, deceptive, stupid and fanatical Muslims. Their physical appearance is not very tall, brownish black skin and has ludicrous formulation of language because every word is repeated. This stereotype is not entirely wrong nor entirely in accordance with the reality. The stereotype tends

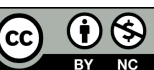

DOI: $10.19105 /$ karsa.v28i2.3057 
to ignore the fact that Madurese are function of complex cultural systems, social organizations and historical processes ${ }^{1}$.

The views arise because there is still little information from experts about this ethnic group. This phenomenon is due to the perception among social sciences-humanities experts that Madurese culture is the tail of Javanese culture. Research on Javanese is tantamount to researching Madura, so there is reluctance to study this culture. When compared with research on other cultures in the scope of the five major archipelago cultural treasures, namely Java, Sunda, Minangkabau, Bali and Madura, research on Madura is relatively small. The image of Madurese mostly comes from newspapers, television, radio and news from people, not from research results that can be accounted for academic. ${ }^{2}$

Among the differences between Java and Madura, for example, are found in their unique settlement patterns. In Java, the settlement patterns of the community are grouped and integrated each other. This allows the emergence of villages is not only as administrative units but also social units so that the village becomes one of the important social identities. Meanwhile, Madura has quite different condition. Madurese settlement pattern is scattered in groups called tanean lanjeng, which are collections of houses with an average of five to eight or more, one settlement with other settlements is isolated. Tanean lanjeng is a long yard with houses built lined up extending from east to west and facing south. In some cases, two lines are facing each other because of the limited land area and the increasing number of families. Tanean lanjeng group is united by the genealogical ties so that the meaning of family in the social structure of Madurese community is significant. Insult to family members of tanean lanjeng is a disgrace to other family members. Then the occurrence of carok, fighting using weapons, definitely involves one tanean lanjeng community with another tanean

${ }^{1}$ Huub de Jonge, "Streotypes of the Madurese," in Across Madura Strait: The Dynamics of an Insular Society, ed. Cornelis van Dijk (Leiden: Koninklijk Instituut voor Taal-Land-en Volkenkunde (KITLV) Press, 1995), 23.

${ }^{2}$ Mien A. Rifa'i, Manusia Madura: Pembawaan, Perilaku, Etos Kerja, Penampilan dan Pandangan Hidupnya (Yogyakarta: Pilar Media, 2007), 75.

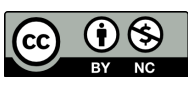

DOI: 10.19105/karsa.v28i2.3057 
lanjeng. Therefore, in Madura, there is almost never a brawl between villages as generally found on Java. ${ }^{3}$

Tanean lanjeng settlement is an essential identity of the Madurese which has not received much attention. ${ }^{4}$ Due to rapid developments occurred in cities, this pattern of settlements has been replaced by newer patterns. Whereas outside urban areas, such patterns are still maintained, even in some areas such as Probolinggo, Situbondo, and Pasuruan, the cultural landscape is still thick with Madurese. Therefore this paper will then examine the pattern of tanean lanjeng settlements by using Levi Strauss's structuralism approach. This approach is used to describe the structure and way of thinking of Madurese in understanding themselves and their world, and how the position and significance of Islam in the structure, which is different from Islam in Javanese society. In this context, it should be emphasized at the outset that this discussion emphasizes the importance of culture as a generic factor, although its differential aspects are also crucial to be carried out. Tanean lanjeng pattern becomes a symbol of the code of conduct of Madurese community life ${ }^{5}$, although as culture in general, it

\footnotetext{
${ }^{3}$ Kuntowijoyo, Perubahan Sosial dalam Masyarakat Agraris: Madura 1850-1940 (Yogyakarta: Mata Bangsa, 2002), 12-15; Latief Wiyata, Carok: Konflik Kekerasan dan Harga Diri Orang Madura (Yogyakarta: LKiS, 2002), 37-38.

${ }^{4}$ Among the studies that paid serious attention to Tanean Lanjeng were Edi Susanto, "Ruh Islam Dalam 'Wadag' Lokal Madura: Kasus 'Tanean Lanjeng,'” Karsa 14, no. 2 (2008): 142-47. This paper tries to put tanean lanjeng as a manifestation of acculturation of Islam in the local culture of Madura that deserves to be appointed to reject the authenticity of Islam. In addition, Latief Wiyata in his book puts tanean lanjeng as a locus of carok events that occur in Madurese community. Wiyata, Carok: Konflik Kekerasan dan Harga Diri Orang Madura, 38-45. Lintu Tulistyantoro tries to explore the meaning of tanean lanjeng socially and functionally. Lintu Tulistyantoro, "Makna Ruang Pada Tanean Lanjang di Madura," Dimensi Interior 3, no. 2 (2005): 137-52. Some other Madurese researchers such as Huub de Jonge and Kuntowijoyo in some of their works do not provide a sufficient portion of the study of tanean lanjeng as an important element in Madurese culture.

5 Retno Hastijanti, "Pengaruh Ritual Carok Terhadap Permukiman Tradisional Madura," Dimensi Teknik Arsitektur 33, no. 1 (2005): 9-16.
}

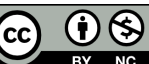

DOI: $10.19105 /$ karsa.v28i2.3057 
must be placed in the arena of power contestation and relations between elements that also determine its transformation over time. ${ }^{6}$

\section{Methods}

To answer the problems, the tanean lanjeng patterns found in Madura will be analyzed through Levi Strauss's Structuralism approach. Structuralism in Levi Strauss's view is an approach that tries to see the basis behind the visible reality. The basis is no longer merely a function of a thing but is a structure of values and cognitions that shape the ideas and actions of a person or society. The concept of Levi Strauss's thinking distinguishes it from other structural thinkers such as RadcliffeBrown. Brown, through his structural-functional theory, sees structure as something that is realized and through something that can be observed. However, Levi Strauss has the opposite view, the structure is behind the observed reality, it is not realized, and it is the core of order that forms something in concrete reality. Levi Strauss assesses structure as something that explains why such a configuration can occur while Brown is more on the existence of a link between concrete reality and structure. $^{7}$

According to Levi Strauss, structures that are at the level of unconsciousness always present in every culture. Therefore the structure is universal, in the sense that similarities in cultural appearance are based on the same structure. This view confirms that Levi Strauss opposed human subjectivity. He does not deny the existence of subjectivity but that is not important. What determines is the pattern of order he calls 'structure'. This thought was evident when Levi Strauss spoke about language. In line with Ferdinand de Sausure, he argued that culture is basically equivalent to language. Language in this sense is not only understood as limited text, but every element of culture such as rituals,

${ }^{6}$ Irwan Abdullah, Konstruksi dan Reproduksi Kebudayaan (Yogyakarta: Pustaka Pelajar, 2007), 7-10.

${ }^{7}$ George Ritzer and Barry Smart, Handbook of Social Theory (London California, and New Delhi: Sage Publication Ltd., 2001), 253-254.

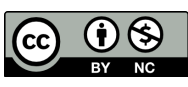

DOI: $10.19105 /$ karsa.v28i2.3057 
performances, settlement patterns, etc. is also text and therefore can be treated as a language. ${ }^{8}$

In Levi Strauss's structuralism, there are concepts about structure and transformation. Structure is a model created by a researcher to understand or explain the symptoms of the analyzed culture which have nothing to do with the empirical phenomenon of the culture. This model is relations that relate to each other and influence each other. Structure is nothing but the relation of relations. Furthermore, Levi Strauss distinguishes structures into two types, namely surface structure and deep structure. Surface structures are related elements that are made based on empirical appearance, while internal or deep structure is a certain arrangement that is successfully built based on the structure of birth but cannot always be referenced by its empirical reality. Cultural changes occur at the level of the external structure, while at the level of the inner structure, it does not change at all. This is what structural studies call transformation, which is the change in the outer forms of a culture. ${ }^{9}$

Therefore, the purpose of this study is to formulate the internal structures of Madurese culture through its empirical appearance in the form of tanean lanjeng settlements. The settlement pattern is seen in the context of the social and ecological life of the Madurese community to then look for the outer structure and their relations with each other. Existing relationships are studied synchronously to understand their meaning if they are placed with other phenomena at a certain point of time. Synchronic relations take precedence over diachronic relations and therefore do not refer to the law of cause and effect but refer to the law of transformation. ${ }^{10}$ The relations above can be further squeezed into binary opposition. The elements in tanean lanjeng are not positioned on

${ }^{8}$ Heddy Shri Ahimsa-Putra, Strukturalisme Levi Strauss: Mitos Dan Karya Sastra (Yogyakarta: Kepel Press, 2006), 66.

${ }^{9}$ Claude Levi Strauss, Antropologi Struktural (Yogyakarta: Kreasi Wacana, 2005), 376.

${ }^{10}$ George Ritzer and Douglas J Goodman, Teori Sosiologi Modern (Jakarta: Prenada Media, 2003), 266.

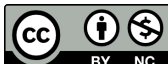

DOI: 10.19105/karsa.v28i2.3057 
their own. Each has an oppositional connection that contains messages both social and individual. Those are what will become basis to determine the internal structures of Madurese culture.

\section{Result}

\section{Madurese Ecology and Tanean lanjeng Concept}

Unlike Java which developed rice fields' economic system, Madura was more familiar with tegal (dry field; Java) economic system. The existence of tegal has been widely known, but it is no much known as an agricultural system. Researches on the strong influence of the agricultural system on Indonesian society have focused on two types of agriculture, namely the ecology of rice fields and fields, while tegal is not yet widely known. Madura with its legal system is a special case that has its own style. Upland land is planted from year to year without rest except for short periods of time for rain. Tegal is the main type of Madurese agriculture, unlike in Java where rice farming is dominant. Madurese consider that tegal is not as mere additions to the economy of rice farming, tegal does not merge with the village structure. Instead rice fields are not as important as tegal. Villages in Madura are closed by tegal and not vice versa, as shown in the usual pattern of village settlement. ${ }^{11}$

One manifestation of the ecology of tegal is a pattern of residential settlement in the form of tanean lanjeng. In a small part of Madura, especially those that have fertile land on the south coast, there are indeed rice fields such as on Java. Resident settlements are located in rice fields with green-fenced, hidden in the shade of trees, look like islands in the middle of sea of paddy fields, and consists of krajan (core) villages with small hamlets. However, the typical village in Madura consist almost entirely tegal ecology. Tegal area consists of a very small group of units, each with its own fields and livestock, more like a farm or small hamlet in Netherlands. People do not live in village, but they live in groups of four or five families in a separate yard, surrounded by walls or fences. Usually they live in a family relationship, even though

${ }^{11}$ Moh. Hefni, "Local Knowledge Masyarakat Madura; Ekologi Tegal di Madura," Karsa 14, no. 2 (2008): 131-41.

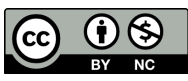

DOI: $10.19105 /$ karsa.v28i2.3057 
they are physically separated. The concept of village in Madura is different from village in Java. The village in Madura is only one territorial area which during the reign of native and Dutch kings was used as an administrative unit. The social unit in Madura is a yard or group of houses called tanean lanjeng.

Tanean lanjeng presents in almost all rural areas of Madura ${ }^{12}$, it is collections of houses with an average of five to eight or more, one settlement with another settlement are isolated. Tanean lanjeng is a long yard with houses built lined up extending from east to west and facing south. In some cases, it is made two lines facing each other because of the limited land area and the increasing number of families. Tanean lanjeng in the literal sense is "long yard". In the yard, there is a house (bungkoh), a kitchen (depor), a cage (kandheng), and a little mosque (kobung). In principle, all houses are built facing south. The kitchen and house were built in front of it face to face. Little mosque (kobung) is located in the west and at night the mosque is used by older boys to sleep. Around the yard, there are trees, shrubs, and other plants that make the settlement closed from outside view. First of all, the plants are reinforced by bamboo fences as protection and are increasingly growing into lush bamboo clumps. In addition, there are other plants to meet daily needs such as vegetables, fruits, flowers, spices, coconut trees, siwalan and memba (bitter leaves). Banana trees and papaya are planted in between the buildings. Every tanean lanjeng has an entrance, so it is considered impolite if outsiders enter by passing the fence. A guest must ask permission from one of the occupants if they want to enter the yard. ${ }^{13}$

\footnotetext{
${ }^{12}$ Latief Wiyata distinguishes between tanean lanjeng and meji village. According to him the two things are different, the first is the tradition in East Madura while the second is developed in Western Madura. However Wiyata did not succeed in showing the differences between the two explicitly. The author believes the opposite, the two concepts actually refer to the same reality. Wiyata, Carok: Konflik Kekerasan Dan Harga Diri Orang Madura, 38-45.

${ }^{13}$ Huub de Jonge, Madura dalam Empat Zaman Pedagang, Perkembangan Ekonomi dan Islam (Jakarta: Gramedia, 1989), 16.
}

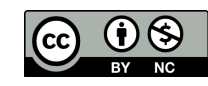

DOI: 10.19105/karsa.v28i2.3057 
Images of Tanean lanjeng

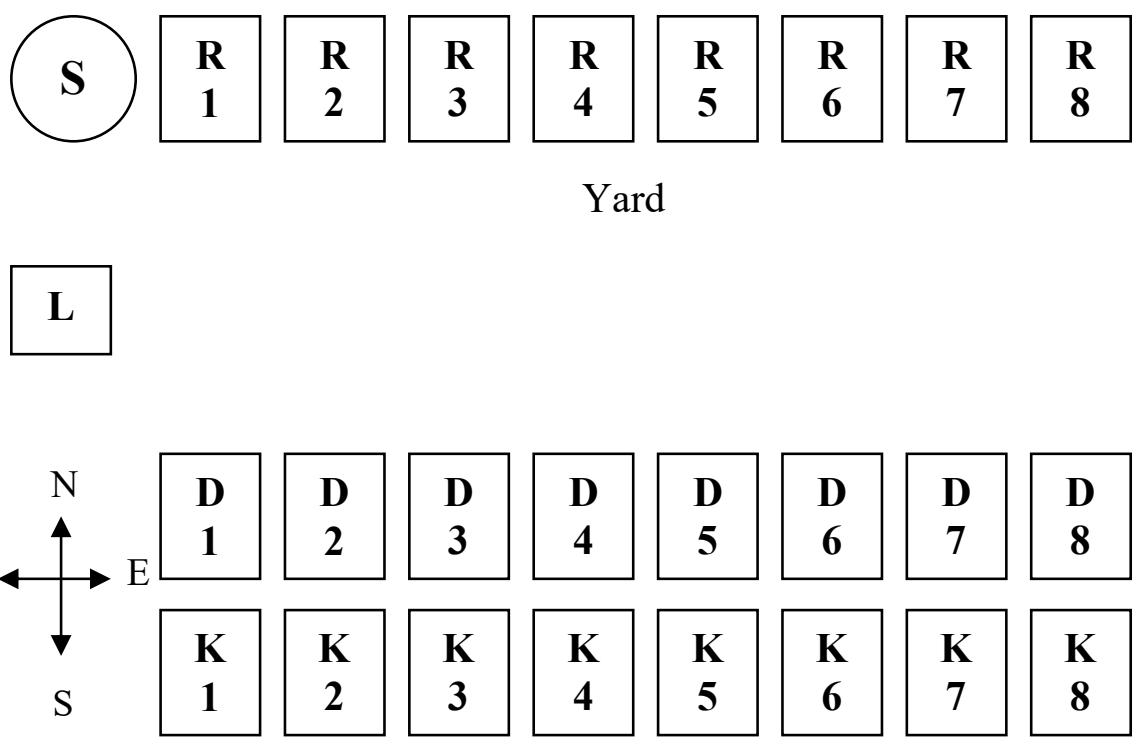

\section{Caption:}

R1, R2, etc. = Houses occupied by each family

$\mathrm{S}=$ Joint well

$\mathrm{L} \quad=$ Little Mosque

D1, D2, etc. = Kitchen for each house, it is also used for food storage

$\mathrm{K} 1, \mathrm{~K} 2$, etc. $\quad=$ Livestock pens for each house ${ }^{14}$

${ }^{14}$ This sketch is the result of the author's observation in several villages in Pamekasan, Madura on June 15, 2018, and also observations during September-October 2018 in Probolinggo, an area in East Java with a strong influence on Madurese culture. Compare also with Tulistyantoro, "Makna Ruang Pada Tanean Lanjang Di Madura," 139.

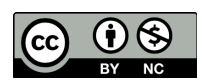

DOI: $10.19105 /$ karsa.v28i2.3057 
The group that lives in Tanean Lanjeng is a genealogical group, married couples are required to live in Tanean lanjeng together with parents of women in a house specifically built for them. Each house is occupied by one family, but sometimes it can be more. If more than one family is occupied in one house, it means that the house consists of parents plus a family of their daughters who are married but have not been able to build a new house. This is logical because of the matrilineal marriages of the Madurese.

Houses in tanean lanjeng are always built in rows from west to east and almost always face south according to the birth order of daughters of the family. The first daughter ranks first, and so on with girls born later. Thus, the number of houses built in accordance with the number of girls born, it does not include the parent house where the parents live. For example, if there are seven houses in a tanean lanjeng, there are six girls who are born there. This is because marriage in Madura adheres to an uxorial-matrilineal system in which married girls remain in their parents' house while married boys move to the house of their wives or in-laws. In its formation, one tanean lanjeng consists of less than eight families, but in Sumenep, appointed by Latief Wiyata, one tanean lanjeng consists of 12 houses inhabited by 11 families. Each family consists of two to four people so that the number of people living there is 41 people, 18 men and 23 women. ${ }^{15}$

The first house located in the northwest is the origin and thus becomes the most important. What determines the next sequence is marriage, but it is rare for a younger girl to marry first. Usually parents have already sought out potential husbands for their daughters when they were young. After parents died, all the residents moved. The oldest daughter occupies the home of the parents and the second daughter occupies her sister's house, and so on. The first son-in-law is now the new head. A change occurs if the daughter whose grandparents are still alive is married. In order for the daughter to stay near her parents, she

15 Muthmainnah, Jembatan Suramadu: Respon Ulama Terhadap Industrialisasi (Yogyakarta: LKPSM, 1989), 26.

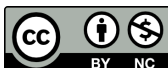

DOI: $10.19105 /$ karsa.v28i2.3057 
built a house near her parents' house. The family yard will become longer and longer but in general cases; it only consists of nine houses. Sometimes one house consists of two families that are separated by bamboo walls. However, if the family members become large and cannot be accommodated, it is decided to establish a new tanean lanjeng.

A yard (house), in principle, should not take much space especially occupying agricultural land which is important to support all family members. New houses could be erected to the south of the house to displace the kitchen and cages. In this case married girls, live in the south on the left side of the parents. This at first glance contradicts the Madurese concept of "west-east", but this is actually an inverse application of extraordinary situations. Likewise there are some deviations from the general case, both regarding the composition of the residents and the housing area. Someone who only has boys prefers some of their sons to live with him. Parents who are too old or sick can move to less important places in the yard. Empty houses are rented by their owners to distant families, neighbors, or to profit sharing farmers.

Although tanean lanjeng is inhabited by more than one family, core families remain the most important social unit. Every family takes care of its own household and controls a certain piece of land, but among these families there are strong ties and cooperation. Residents help each other in carrying out work and often have livestock and agricultural equipment together. The women help each other in shopping, cooking, and taking care of their children. Even though a family lives with parents and sisters, the Madurese family can be ensured to be economically independent. This can be seen from the existence of a kitchen in every family. However, as described above, the presence of one well and one violate indicates the existence of strong bonds that are interwoven. Langgar (little mosque) can be both a place of worship; it is also useful as a living room, especially for male guests who are not relatives. Thus it can be concluded that sociologically, tanean lanjeng settlements do not only consist of nuclear families but also extended families.

In Madura, village is an administrative unit which in a certain period is not very important. It is different from Java where the village is a solid unit with strong local government, communal land ownership,

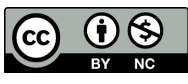

DOI: $10.19105 /$ karsa.v28i2.3057 
and a limited place where most of the population lives. On the contrary, the village in Madura consists of a group of scattered farmer and hamlet houses which are located along the coast consisting of small hamlets. Village government is not strong enough. Village meetings to discuss issues of village interest are unknown or rarely held. In fact, almost all land belongs to individuals. So a village territory in Madura consists of several sub-villages, consisting of several tanean lanjeng, and tanean lanjeng consisting of several families. It is conceivable that a house group was originally a single house. In each village settlement, an individual is only bound by the closest social group in Tanean lanjeng where their home and family are located. Villages in Madura are difficult to identify. The absence of such boundaries made it easier for the government to change or reorganize the village administration unit because there was no opposition from the population. The feeling of togetherness and solidarity at the village has a little development. The loose village ties were caused by the existence of separate dwellings, individual land ownership and changing village divisions or the merging of villages during the power of indigenous kings for the benefit of the apanage system. Also due to the influence of mobility of Madurese who are looking for work elsewhere outside their villages.

Religious and cultural institutions contribute little to the village's social life. Almost every family has its own mosque as a place for religious education and is rarely used for all villages habitant. The village mosque, if exist, is only used for Friday prayers. The lack of village ties is also shown by the absence of an ancestor of the village. Nevertheless they have an annual party arranged by the village head or kliwon, or based on the annual village calendar arranged by the village head, or is also based on traditional calendars. In the annual party, there are several religious and customary ceremonies that will bring people to get along with each other. ${ }^{16}$

${ }^{16}$ Muthmainnah, 32.

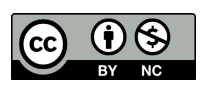

DOI: $10.19105 /$ karsa.v28i2.3057 


\section{Discussion}

\section{Structural Analysis of the Tanean lanjeng Pattern}

Having understood well the tanean lanjeng pattern in Madurese society, it will be easier to look for binary opposition, both in the direction and location, the distribution of gender, family or non-family, and so on. Oppositions are needed to determine the relationships between the elements so that later the structure of the Madurese community will be found. The binary opposition contained in the tanean lanjeng concept is as follows:

1. Opposition oreng lake'- oreng bini' (male-female);

2. Opposition oreng delem-oreng luar (insiders-outsiders);

3. Opposition marries relatives and outsiders;

4. East-west opposition.

Oppositions above are conclusions from the analysis of the concept of tanean lanjeng which must be compared with the ethnography of Madurese community. Without sufficient ethnographic data, the oppositionist relations will have no meaning. This is due to the fact that various opposition relations in Tanean lanjeng must be sought for the alignment and explanations in the daily social and cultural life of Madurese community.

\section{Opposition oreng lake'- oreng bini' (male-female)}

As explained above, the Taneng settlement is indeed intended for the descendants of women, while the male must live in his wife's house, although in some cases there are exceptions. The more someone has a daughter, the more she has the responsibility to build a house. The quality of the house depends on the economic capabilities. For parents who do not economically make it possible to build new homes when their daughters marry, the parent room is occupied for their children while they simply occupy the back room or even become one with the kitchen. This is caused that Madurese community assuming that a woman must be protected because it is part of her honor. She must be placed in an area that is safe from interference, both from disturbances of wild animals and men. A form of interference with a woman is a disgrace to her husband or brother so that the aggrieved party must reciprocate. As explained by Latief Wiyata, most of the carok (a fight

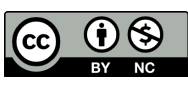

DOI: $10.19105 /$ karsa.v28i2.3057 
by using sword) events were caused by harassment of women. Women are considered unable to protect themselves and therefore must be protected by strong men. Parent's responsibility is to give daughter a home that is safe and make her have the bargaining in front of her husband. While the responsibility of a husband is to protect his wife from any disturbance so that the kitchen in Tanean lanjeng is always in front of the house, similar to the location of the cage which is also in front of the house. This is because a woman is always under the supervision and protection of her husband, although she is in the kitchen ${ }^{17}$.

Madura's nature and social environment are hard to cause an unsafe atmosphere for women. Land in Madura is infertile and in the dry season, water is hard to come by, residents require to cultivate fields and work hard to get water. This kind of task is mostly done by men even though a Madurese woman also takes part in cultivating the fields, helping her parents or husband. Far distance of one settlement to other makes security difficult to guarantee especially at night. Therefore a wife walks behind her husband who is nyekep (carrying a sharp weapon tucked behind her shirt). A Madurese man wears a traditional pesa or gombor, which is loose that makes him free to move and show off his sturdy body. Whereas a woman wears traditional clothes that are rather tight and usually wears anklets made of metal. For rich families, the anklet can be made of gold.

The attention and protection of Madurese towards women is also seen in the existence of langgar (village). Every tanean lanjeng must have a langgar. The location is always in the western part which does not only mean religious but serves as a living room for all male guests who are not close relatives. The main purpose of placing all male guests in langgar is to prevent the possibility of negative sexuality-related behaviors due to a meeting between the male guest and the female family member as the host. For Madurese, it is parseko (unethical) if they receive male guests in the living room, except those who are still

${ }^{17}$ Wiyata, Carok: Konflik Kekerasan dan Harga Diri Orang Madura, 44.

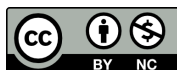

DOI: $10.19105 /$ karsa.v28i2.3057 
close relatives. Therefore, every male guest will go to langgar and at this place he will meet the male host. If a guest comes with his wife, only the wife can enter living room. In this place, she meets the wife or relatives of the host woman. If the male host is not at home, then the guest can only greet from the room without revealing himself. Finaally the guest must go home immediately and not waiting for the host. Thus, women are protected from all forms of sexual harassment.

Unlike women, a man in Madura is required to be independent and strong from childhood. Since they were teenagers, they do not sleep at home but in langgar (mosque). This habit reflects that a man is used to being separated from his family because in the end they have to go either because they migrate or because they are married so they have to follow his wife. Since childhood, they have to help $\mathrm{f}$ their parents to work so that they are trained to work hard and are equipped with skills to be economically independent. After marriage they are accustomed to work. A Madurese man is judged from his skills at work because he has to live outside his family. In addition, it was also from his courage to defend the honor of himself and his family. Carok is almost always carried out by men because of abstinence for a man to fight with women. If a man is capable in carok, it is a matter of pride for himself and his family. This is reflected in Madurese proverb 'reng lake' mate carok, reng bini' mate arembi" " (a man dies because of carok while a woman dies for giving birth).

Gender differences in Madurese society bring a special relationship. On the one hand women are indeed positioned as human beings who are weaker than men, but on the other hand women also enjoy a certain privilege that is not enjoyed by men, such as getting a house and land rights. It is women who have the right to manage their parents' inheritance, in the form of houses and land, and become a place for their brothers to complain. In everyday life, the husband is indeed placed in a more important position so that a wife is required to abasa (using fine language) to her husband otherwise the husband only needs to mapas (using ordinary language) to his wife. Because of his ownership of the house, the wife has comparable power to the husband because she owns the rights to land and housing, while the husband plays a role in processing it as a source of life for the whole family.

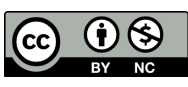

DOI: $10.19105 /$ karsa.v28i2.3057 
Therefore, polygamy for Madurese society is unknown. It is difficult for a husband to have more than one wife because he only stays in his wife's house. In tanean lanjeng, the power of women and men is comparable ${ }^{18}$.

\section{Opposition oreng delem-oreng luar (insiders-outsiders)}

Oreng delem are people who are still bound by kinship, while oreng luar is a person who has no kinship at all. All members who inhabit one tanean lanjeng are brothers, while outside are those who have kinship relations and some who are not at all. The bond between fellow residents of tanean lanjeng is very strong. Madurese really appreciate kinship relationships, including relatives with different tanean lanjeng with him. To maintain strong intimacy between relatives, they carry some social activities such as visiting each other, both when they are happy (events, engagements, marriages, etc.) or grief (sick, death, calamities, etc.). Even to maintain integrity and re-establish kinship ties that are considered to be almost breaking up, Madurese have a habit of conducting marriages between family members or kin-group endogamy. Whereas, the relation is loose to those who are not relatives. This is due to the fact that between one settlement and another settlement is quite far apart for making communication. The meaning of the village in Madura is quite general, in the sense that if someone in Java refers to the village where he lives then it does not happen in Madura. However, this does not mean that there is no social interaction in Madura. The interaction is still well built through the relationship of work, marriage, religious rituals, and social ceremonies that bring them together. The existence of tajin sora and tajin sappar ${ }^{19}$, rebbe as part of the celebration of the feast, etc. shows the existence of social cohesiveness.

\footnotetext{
18 Moh. Hefni, "Bhuppa'-Bhâbhu'-Ghuru-Rato (Studi Konstruktivisme-Strukturalis Tentang Hierarkhi Kepatuhan Dalam Budaya Masyarakat Madura)," Karsa 11, no. 1 (2007): 13-20.

${ }^{19}$ In this case, each family, in turn, will make white sticky rice in Muharram (tajin sora) and black sticky rice in the Shafar month (tajin sappar) in large quantities and distribute it to each family in several tanean lanjeng complexes. The family who
}

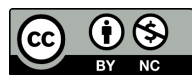

DOI: $10.19105 /$ karsa.v28i2.3057 
The strong bond between Tanean lanjeng members makes internal solidarity between each member very strong. Harassment of dignity towards all family members, especially if it happens to women, will always be interpreted as harassment of the dignity of all family members. If this happens then all tanean lanjeng members will react. For example, for a husband whose wife is disturbed, he will not hesitate to challenge his rival to do carok, which will certainly be supported by all family members. If for some reason, they feel afraid because the enemy is considered to be stronger both for physical and non-physical reasons, the husband does not do carok. Then the defense or role to do carok will be taken by men from other family members. It can be both by tanean lanjeng members and brothers of the husband or brothers of the wife. While other family members will certainly help in the form of morals and material, such as providing financial assistance during carok and after. Then carok event will always be an event of hostility between two large families, more specifically the hostility between the two tanean lanjeng communities.

It does not mean that Madurese always have suspicion and hostility towards outsiders. A person who is not a relative can be considered and treated as a family member if he has a high level of closeness and intimacy. On the contrary, family members can be considered and treated as outsiders if their kinship and closeness are very low due to a dispute. This is indicated by the expression of Madurese oreng in taretan, taretan daddi oreng (other people who are not relative becomes brothers, while a brother become someone else). Even if the dispute increases it is not uncommon for a family member to be considered an enemy. If so, there is a possibility that carok will occur between families. Thus, besides the bond of brotherhood, it is very decisive, the quality of the relationship that is established is also very much determined by the quality of respect for the capacity of each individual. In addition, Madurese are also widely known to appreciate the guests who come, both in the form of hospitality and treats served.

received the shipment has the responsibility to reply to the shipment on the day of turn. Wiyata, Carok: Konflik Kekerasan Dan Harga Diri Orang Madura, 52.

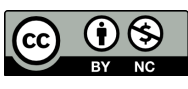

DOI: $10.19105 /$ karsa.v28i2.3057 
3. Opposition is married to a married relative with an outsider

Because of the strong of kinship ties, Madurese tend to do marriages between their own families. Marriage with one's own family is the ideal type of marriage. The marriage is intended to maintain and preserve kinship relations, especially for families who have lived far apart. In Madurese expressions it is called mapolong tolang (collecting bones), which means gathering back family members who are already scattered. For wealthy families, the marriage might be tucked into a purpose of economy. Marriage is intended to protect the property that is owned not fall into the hands of outsiders. However, in Madurese culture, there are also marriages between family members which should be avoided, between children from siblings called arompak balli. According to public trust, if the marriage is done, it will bring havoc to the concerned.

In the reality of traditional Madurese communities, Madurese match their children under the age of five with children from other families at the same age. There are even those who match their children when the child is still in the womb. ${ }^{20}$ It is not surprising then that there are many forced marriages. The purpose of matching children is also to maintain the honor of the family from feeling ashamed if in future their daughter has not found a husband. Madurese do not want a woman live alone without a male companion as a husband who will protect her honor. To avoid that, it is understandable if the initiative to match almost always comes from the parents of girls. Initiatives that come from men have the same intentions. As a large family, they feel shame if there are members of their relatives who are not married soon. The custom of marrying one's own family is still maintained today, including in areas

\footnotetext{
20 Iwan Kuswandi and Lilik Fadilatin Azizah, "Tradisi Mitos Sangkal dalam Pertunangan Dini Perspektif Kiai di Madura," Indonesian Journal of Islamic Literature and Muslim Society 3, no. 2 (2019): 157, https://doi.org/10.22515/ islimus.v3i2.1391.
}

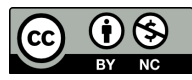

DOI: $10.19105 /$ karsa.v28i2.3057 
where the influence of Madurese culture is very thick ${ }^{21}$. Based on Latief Wiyata's research in Bondowoso, East Java, the people have endogamy with their relatives in Madura, especially when the connection between Java and Madura is getting easier. ${ }^{22}$

\section{East-west opposition}

As mentioned, housing in tanean lanjeng always runs from west to east. Tanean lanjeng always has a langgar (little mosque) on the western side as a place of prayer and other Islamic rituals. After mosque, the main house where the parents live is placed and afterwards lined eastward is the home of their daughter according to the birth order. If the parents die, all the residents move. The oldest daughter occupies the home of her parents and the second daughter occupies her sister's house, and so on. The whole house faces south where a few meters in front a kitchen is and domestic cattle shed. The order of this direction reflects the Islamic level of Madurese. The West is a qibla direction where they pray facing that direction. In the congregational prayer, the imam (prayer leader) is in the west while the other members of the congregation line to the east. All members of the congregation follow the movements of the imam. This is in line with the daily life of Madurese people who always pay homage to the older because they are considered to have more experience and knowledge. The elders are placed in the west as a symbol that they must be respected, while in the east are younger siblings who in certain limits may not disobey older brothers.

Madurese obedience towards older people or figures is reflected in their social structure. Allah, Buppa' (father), babu' (mother), taretan tua (old brother), guruh (role model) and ratoh (king or government) are important figures in the community. ${ }^{23}$ If buppa', babu' and taretan tua

\footnotetext{
${ }^{21}$ Muhammad Latif Fauzi, “Actors and Norms in an Islamic Marriage: A Study of Madura Community in Rural Eastern East Java," Journal of Indonesian Islam 13, no. 2 (2019): 297-325, https://doi.org/10.15642/JIIS.2019.13.2.297-325.

22 A. Latief Wiyata, Taneyan Lanjang: Pola Pemukiman dan Kesatuan Sosial di Masyarakat Madura (Jember: Pusat Kajian Madura Universitas Jember, 1987).

${ }^{23}$ A. Sulaiman Sadik, "Revitalisasi Semangat Bhuppa' Bhăbhu' Ghuru Rato dalam Melihat Madura ke Depan,” Karsa 11, no. 1 (2007): 22-29; Hefni, “Bhuppa'-Bhâbhu'-
}

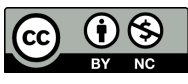

DOI: $10.19105 /$ karsa.v28i2.3057 
are important elements in Madurese family, then guruh and ratoh are determinant elements in the dynamics of social, cultural, political and religious life, whereas Allah influences nature and all dimensions of life. From the social life, it is illustrated that in addition to being obedient to God, father, mother and elder brother, Madurese are expected to also obey to role models and the government. Role models are informal leaders, those who lead the community or a group of influential people who are not associated with government institutions, such as kyai (clerics), blater, elders of the village and so on. ${ }^{24}$

Informal leaders in Madura can be divided into two types, namely kyai and non kyai. Kyai are figures who are respected because of their authority over religious knowledge, have pesantren or are still descendants of clerics. In contrast, non-clerical informal leaders are figures who are socio-culturally gaining legitimacy because of their advantages such blater (in Madura). Blater figures are people who have expertise and courage in fighting one on one or doing carok. Their daily lives often have conflict with religious teachings and have a strong network in the world of crime. They are identified with bad deeds such as gambling, drinking, girls and remo, a type of social gathering with entertainment of traditional dances.

Within certain situation, blater is very submissive to the clerics. There are two reasons why they behave like that; first, they are still learning from the clerics, both in the sense that they have ever studied religion from him or territorially are still under the influence of the clerics. Second, the blater's magic such as not being pierced with sharp weapons, can disappear because of the deeds specifically by a kyai (cleric). This is possible because in Madura, there are two kinds of the clerics, the clerics who are struggling for education and religious propaganda and clerics who have expertise in mystic things and occult.

Ghuru-Rato (Studi Konstruktivisme-Strukturalis Tentang Hierarkhi Kepatuhan dalam Budaya Masyarakat Madura)," 12-20.

${ }^{24}$ Laili Amalia and Hayat Hayat, "Penguatan Kapasitas Budaya Andeb Ashor dan Patronisasi Masyarakat Madura," Jurnal Inovasi Ilmu Sosial Dan Politik 1, no. 1 (2019): 38, https://doi.org/10.33474/jisop.v1i1.2686.

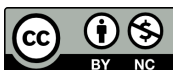

DOI: $10.19105 /$ karsa.v28i2.3057 
It could be that these two skills are possessed by clerics so that they have an influence on blater. Therefore, it is not difficult to explain why Madurese people have great respect for these two opposing figures. Although Madurese are fanatical Muslims, they require obedience to kyai, on the other hand they highly respect the courage and empowerment in carok culture. Thus, this is the legitimacy of the honor of the blater.

Muhammad Zuhri's research finding has proven the need for blater in the socio-cultural life of Madurese community. In his research on the leadership of the headman, he found that Madurese tolerated and even preferred blater as headman. The public is aware that blater behavior violates the rules of religion, but the demand has forced them to be ambivalent. The headman with a blater background is really needed for village security as a symbol of pride and prestige. Many facts show that village security becomes more secure with the presence of a blater being the chief of village. ${ }^{25}$

From the description, it can be concluded that; first, Madura's social structure is very complicated. Within the family sphere, there are fathers, mothers and older siblings as role models, while in a wider life there are figures of clerics, blater and government. Second, the social structure creates a society with a unique cultural system. On the one hand, Madurese culture is strongly influenced by Islam which is later manifested in many ways, and on the other hand the culture of violence remained an important element as a manifestation of the blater leadership.

Back to the issue of tanean lanjeng patterns, the houses built inside always face south. This is also a reflection of the strong religiosity of Madurese. This habit confirms and reminds the provision of burial in Muslim communities, where the head is placed on the north facing south while his face is tilted to the west. The sleeping position of Madurese, in tanean lanjeng formation, always stretches from north to south by placing the head in the north like the position of the dead when buried.

${ }^{25}$ Muhammad Zuhri, "Persepsi Masyarakat Terhadap Kepemimpinan Formal Kepala Desa (Studi Kasus Tentang Perilaku Devian di Kabupaten Bangkalan, Jawa Timur)" (UGM, 1991), 32.

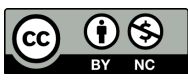

DOI: $10.19105 /$ karsa.v28i2.3057 
The meaning is that in such position, someone, as a devout Muslim, will always remember that at some point he will surely die.

\section{Cognitive Structure and World View of Madurese}

After describing the ecological life and settlement patterns of Madurese and comparing them with the socio-cultural context they have, four alternative relations can be found as mentioned above. The four opposition relations, namely the opposition between men and women, between oreng delem (insiders) and oreng luar (outsiders), between marrying family and marrying non-family and between west and east, do not only refer to how tanean lanjeng is organized, but also show thinking structure and worldview of Madurese ${ }^{26}$. To be easier, it can be described as follows:

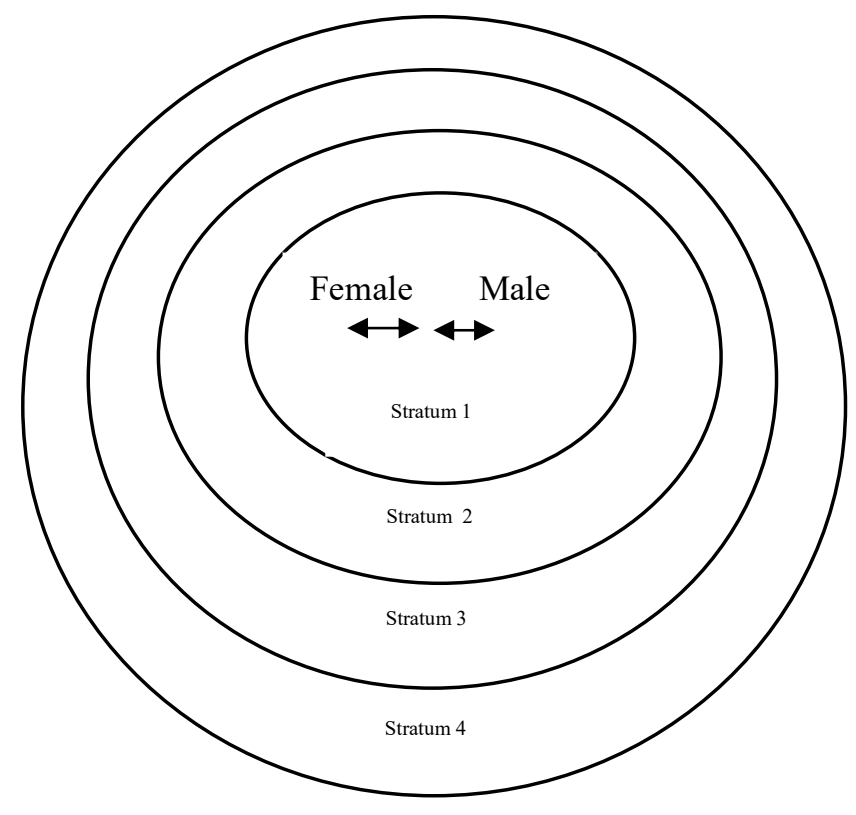

${ }^{26}$ Ainur Rahman Hidayat, "Makna Relasi Tradisi Budaya Masyarakat Madura dalam Perspektif Ontologi Anton Bakker dan Relevansinya Bagi Pembinaan Jati Diri Orang Madura," Jurnal Filsafat 23, no. 1 (2013): 21-32.

\section{(c) (i) (3)}

DOI: $10.19105 /$ karsa.v28i2.3057 
The circle picture consists of layers is actually the world of Madurese formed and that is where their starting point in understanding the world. The first layer in the deepest part is the world of Madurese in tanean lanjeng sphere. The world is the core where they form and finally find their identity. The interaction between members in one tanean lanjeng is so intense that if one of its members suffers or is hurt by the outside community, then they feel it as mutual suffering. Carok that is common in Madurese is basically not individual conflict but rather a conflict between one tanean lanjeng and another tanean lanjeng. Even though the implementation of carok is still carried out individually, one on one, two on two, and so on in a balanced composition. This is what always ties Madurese abroad to return to visit their respective Tanean lanjeng, at least once a year before the Eid Al-Fitr. For those who have succeeded and have money, they will build a house in Tanean lanjeng which will be occupied by other relatives. For outsiders this is a waste, but for Madurese, this is a serious effort to reconnect their identity with a certain space, far away.

Whereas horizontal lines marked with arrows that move away and approach indicate how the relationship between women and men is built. The horizontal line illustrates that the relationship between men and women is egalitarian. Men work in fields to earn a living and are assisted by their wives. However, this does not make the male position dominant as in Java. Women have important power because they have the right to the house and land, so the relationship is balance. This is also evidenced by the unusual tradition of polygamy in Madurese society. The arrow lines that move away and approach mean that the relationship between the two is mutually reinforcing. Many jobs and roles can be done both or one of them. In an extreme condition, carok is the task of men but because of agreement by all tanean lanjeng members, both men and women can do carok. Nevertheless, Madurese still try hard to distinguish the two. Men and women remain different both in position and role, and cannot be reversed. This is reflected in Madurese phrase "reng lake' mate acarok, reng bini 'mate arembi" " (a man dies because of carok while a woman dies from childbirth).

The second layer is sataretanan (brother) which is outside the scope of tanean lanjeng. Madurese really value kinship ties even though

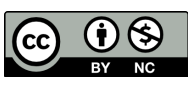

DOI: $10.19105 /$ karsa.v28i2.3057 
they are geographically far apart. Madurese who live in Java can still refer their relatives who live in Madura, and vice versa. They are very appreciative and happy when their relatives who live far away coming to visit. As already mentioned, ideal marriage in Madurese is marriage among one's own relatives. This aims to bring the kinship ties closer together, in other words, marriage between relatives serves to attract families to be close again.

The third layer shows the ethnic side of Madurese people. Madurese are those who are really proud of their Madurese culture they have so that if they live in other ethnic groups, they will form tribal solidarity to help their lives and security. In general, they try their luck by working in the informal sector as freighters, construction workers, scrap metal sellers, food vendors, Pedi cab drivers, satay and soup sellers, and so on. They dissolved to form collaborative networks that transcended ethnographic, descent, social strata and their respective regions. They gather and join in the emotional bond between fellow brothers (sataretanan) migrants with various professions, and they work hand in hand to maintain and preserve the noble cultural values of their homeland, even though they are still categorized as outsiders. While the last layer is the outside world, people who do not have kinship ties or ethnicity. Madurese continue to maintain good relations with other communities and have friendly attitude to the extent that their security and self-esteem are not disturbed.

Regarding western and eastern opposition, this shows the level of Islam and the role of figures in Madurese community. Madurese are widely known as devout Muslims. For them, the west is the center of gravity of all life activities, in that direction, they face the direction when they pray. In the congregational prayer, the prayer leader is always in the westernmost part, in the front position. Therefore the western direction has a higher and sacred special meaning so that settlement arrangements in Tanean lanjeng place older parents and siblings in the westernmost position in sequence. In line with the role of imam (prayer leade), Madurese pays homage to parents and older siblings because they are considered to have more experience and knowledge.

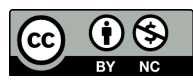

DOI: $10.19105 /$ karsa.v28i2.3057 
In the broader structure of life, the role model is not only God (Allah), buppa' (father), babu' (mother) and taretan tua (old brother). There are also other figures, guruh (role model) and ratoh (king / government). If buppa', babu' and taretan tua are important elements in Madurese family, then guruh and ratoh are determinant elements in the dynamics of social, cultural, political and religious life, whereas Allah is an important figure in all dimensions of life. ${ }^{27}$ From the social term, it is illustrated that in addition to being obedient to God, the father, mother and elder brother, Madurese are expected to also submit to role models and the government. What is meant by role models here are informal leaders; those who lead the community or a group of influential people who are not associated with government institutions, such as clerics, blater, elders of the village and so on. From the description above, it can be illustrated by the model as follows:

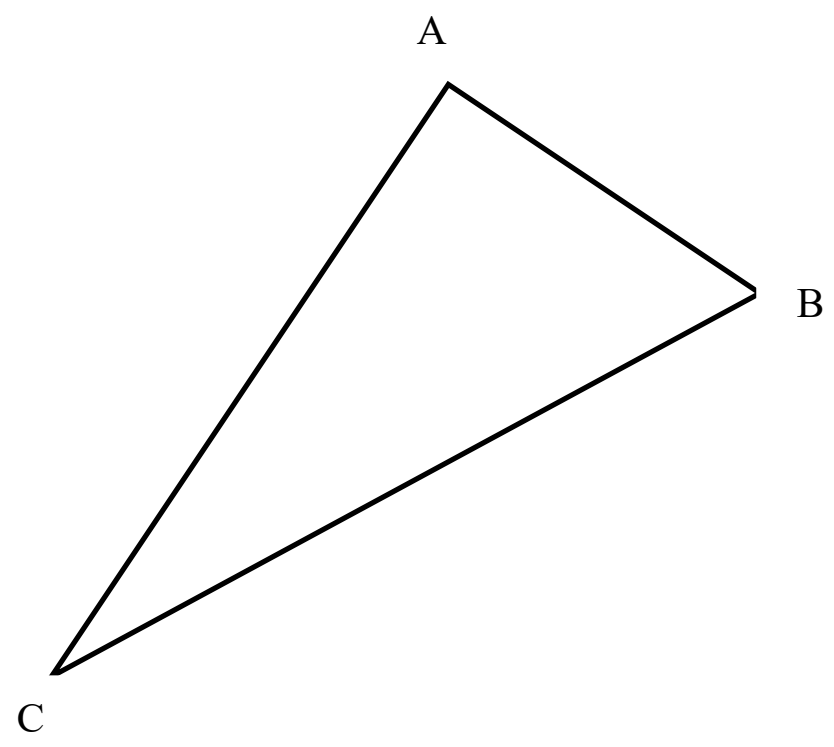

${ }^{27}$ Yanwar Pribadi, "Religious Networks in Madura Pesantren, Nahdlatul Ulama and Kiai as the Core of Santri Culture," Al-Jami'ah: Journal of Islamic Studies 51, no. 1 (2013): 1-32.

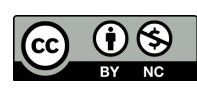

DOI: $10.19105 /$ karsa.v28i2.3057 
This model can be called the "skew triangle" model. A is for God or Islam, B stands for role models, namely buppa' (father), babu' (mother), taretan tua (old brother), guruh (role model; kyai and blater) and ratoh (king or government), while $\mathrm{C}$ is a representation of individuals or society. The three have a close relationship. An individual or community $(\mathrm{C})$ has an obligation to obey and respect $\mathrm{B}$ because $\mathrm{B}$ has the knowledge and experience to direct life of $\mathrm{C}$ on the path of salvation, while $\mathrm{B}$ has an obligation to implement the teachings of $\mathrm{A}$ in everyday life so that B really becomes a true role model. Likewise, $\mathrm{C}$ must obey A higher than obey B. If $\mathrm{B}$ no longer follows the teachings of $\mathrm{A}$ then there is no obligation on $\mathrm{C}$ to obey $\mathrm{B}$ more, even though respect for him is often maintained. This explains why the role of the clerics is stronger than the role of the government because kyai is a religious figure that is closer to A, while the government often shows opposite behavior to A. The description shows clearly that Islamic influence is deeply rooted in awareness and practice of Madurese community. ${ }^{28}$

\section{Conclusion}

Through Levi Strauss's structuralism approach, it is clear that tanean lanjeng not only have practical and social functions but show certain meanings that reflect the structure of thinking and the worldview of Madurese people who are attached to Islamic values. Even though such settlement patterns have begun to change with the inclusion of new housing models, especially in cities, Madurese thinking structure has not changed. As described above, values such as equality of male and female relations, strong kinship ties, respect for certain figures, and

\footnotetext{
${ }^{28}$ Paisun, "Dinamika Islam Kultural; Studi Atas Dialektika Islam dan Budaya Lokal Madura," El-Harakah 12, no. 2 (2010): 154-68. When compared to the identification of Islam with ethnicity, between ethnic Javanese and Madurese, it is difficult to imagine Madurese people embracing beliefs other than Islam, whereas in Javanese people, the identification is more loose. Even if we agree with Thomas Raffles, Clifford Geertz, and James L. Peacock, Islam is a thin layer in Javanese culture.Ahmad Najib Burhani, Muhammadiyah Jawa (Jakarta: Al-Wasat Publishing House, 2010), 11 12.
}

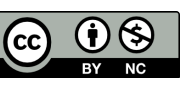

DOI: $10.19105 /$ karsa.v28i2.3057 
Islam deeply rooted in a structure that determines how Madurese behave, shape culture and interpret the world around.

\section{Bibliography}

Abdullah, Irwan. Konstruksi Dan Reproduksi Kebudayaan. Yogyakarta: Pustaka Pelajar, 2007.

Ahimsa-Putra, Heddy Shri. Strukturalisme Levi Strauss; Mitos Dan Karya Sastra. Yogyakarta: Kepel Press, 2006.

Amalia, Laili, and Hayat Hayat. "Penguatan Kapasitas Budaya Andeb Ashor dan Patronisasi Masyarakat Madura." Jurnal Inovasi Ilmu Sosial dan Politik 1, no. 1 (2019): 38. https://doi.org/10.33474/ jisop.v1i1.2686.

Burhani, Ahmad Najib. Muhammadiyah Jawa. Jakarta: Al-Wasat Publishing House, 2010.

Fauzi, Muhammad Latif. "Actors and Norms in an Islamic Marriage: A Study of Madura Community in Rural Eastern East Java." Journal of Indonesian Islam 13, no. 2 (2019): 297-325. https://doi.org/10. 15642/JIIS.2019.13.2.297-325.

Hastijanti, Retno. "Pengaruh Ritual Carok Terhadap Permukiman Tradisional Madura." Dimensi Teknik Arsitektur 33, no. 1 (2005): 9-16.

Hefni, Moh. "Bhuppa'-Bhâbhu'-Ghuru-Rato (Studi KonstruktivismeStrukturalis Tentang Hierarkhi Kepatuhan dalam Budaya Masyarakat Madura).” Karsa 11, no. 1 (2007): 13-20.

. "Local Knowledge Masyarakat Madura; Ekologi Tegal di Madura." Karsa 14, no. 2 (2008): 131-41.

Hidayat, Ainur Rahman. "Makna Relasi Tradisi Budaya Masyarakat Madura dalam Perspektif Ontologi Anton Bakker dan Relevansinya Bagi Pembinaan Jati Diri Orang Madura." Jurnal Filsafat 23, no. 1 (2013): 21-32.

Jonge, Huub de. Madura dalam Empat Zaman Pedagang, Perkembangan Ekonomi dan Islam. Jakarta: Gramedia, 1989. . "Streotypes of the Madurese." In Across Madura Strait: The Dynamics of an Insular Society, edited by Cornelis van Dijk, 23. Leiden: Koninklijk Instituut voor Taal-Land-en Volkenkunde (KITLV) Press, 1995.

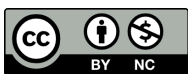


Kuntowijoyo. Perubahan Sosial Dalam Masyarakat Agraris; Madura 1850-1940. Yogyakarta: Mata Bangsa, 2002.

Kuswandi, Iwan, and Lilik Fadilatin Azizah. "Tradisi Mitos Sangkal dalam Pertunangan Dini Perspektif Kiai di Madura." Indonesian Journal of Islamic Literature and Muslim Society 3, no. 2 (2019): 157. https://doi.org/10.22515/islimus.v3i2.1391.

Muthmainnah. Jembatan Suramadu; Respon Ulama Terhadap Industrialisasi. Yogyakarta: LKPSM, 1989.

Paisun. "Dinamika Islam Kultural: Studi Atas Dialektika Islam dan Budaya Lokal Madura." El-Harakah 12, no. 2 (2010): 154-68.

Pribadi, Yanwar. "Religious Networks In Madura Pesantren, Nahdlatul Ulama and Kiai as the Core of Santri Culture." Al-Jami'ah: Journal of Islamic Studies 51, no. 1 (2013): 1-32.

Rifa'i, Mien A. Manusia Madura; Pembawaan, Perilaku, Etos Kerja, Penampilan Dan Pandangan Hidupnya. Yogyakarta: Pilar Media, 2007.

Ritzer, George, and Douglas J Goodman. Teori Sosiologi Modern. Jakarta: Prenada Media, 2003.

Ritzer, George, and Barry Smart. Handbook of Social Theory. London California, and New Delhi: Sage Publication Ltd., 2001.

Sadik, A. Sulaiman. "Revitalisasi Semangat Bhuppa' Bhăbhu' Ghuru Rato Dalam Melihat Madura Ke Depan." Karsa 11, no. 1 (2007): 22-29.

Strauss, Claude Levi. Antropologi Struktural. Yogyakarta: Kreasi Wacana, 2005.

Susanto, Edi. "Ruh Islam Dalam 'Wadag' Lokal Madura: Kasus Tanean Lanjeng." Karsa 14, no. 2 (2008): 142-47.

Tulistyantoro, Lintu. "Makna Ruang Pada Tanean Lanjang Di Madura." Dimensi Interior 3, no. 2 (2005): 137-52.

Wiyata, A. Latief. Taneyan Lanjang: Pola Pemukiman dan Kesatuan Sosial di Masyarakat Madura. Jember: Pusat Kajian Madura Universitas Jember, 1987. 
Wiyata, Latief. Carok: Konflik Kekerasan dan Harga Diri Orang Madura. Yogyakarta: LKiS, 2002.

Zuhri, Muhammad. "Persepsi Masyarakat Terhadap Kepemimpinan Formal Kepala Desa (Studi Kasus Tentang Perilaku Devian di Kabupaten Bangkalan, Jawa Timur).” UGM, 1991. 